\title{
6
}

\section{'DEVELOPMENT' PERSPECTIVES FROM THE GLOBAL SOUTH}

\section{Learning from Ubuntu and Buen Vivir philosophies}

\section{Birgit K. Boogaard and Dorine E. van Norren ${ }^{7}$}

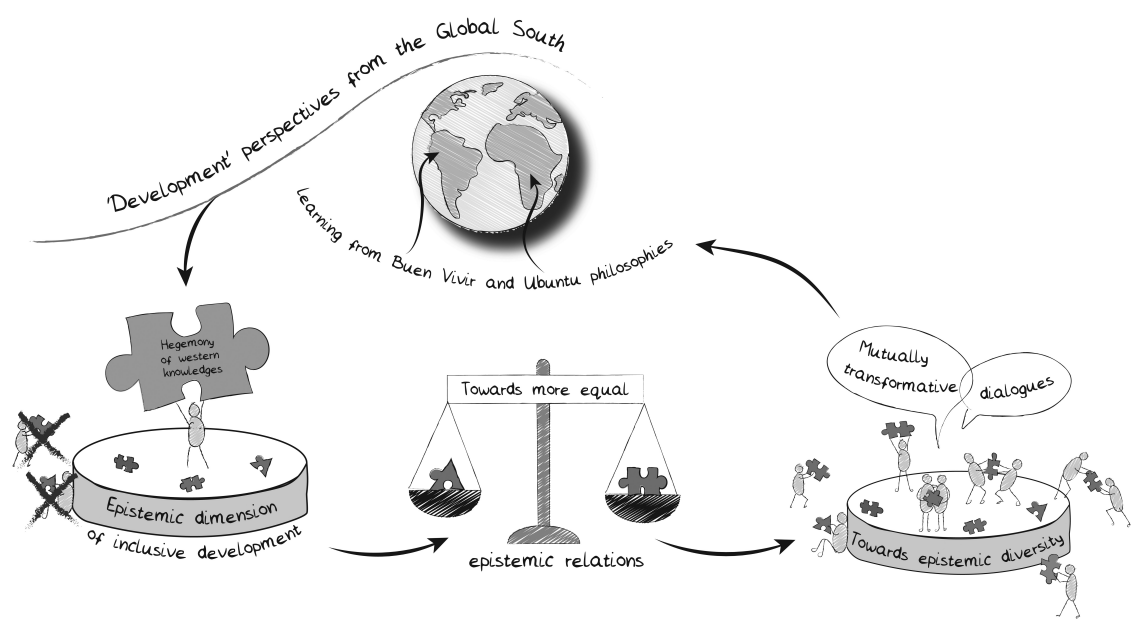

\section{Introduction}

While it is widely acknowledged that 'development' is an inherently Eurocentric concept (e.g. Ziai and Escobar, 2007), wellbeing concepts from perspectives of the Global South are less well known, let alone embraced. ${ }^{2}$ The fact that development is a Eurocentric concept, however, may not necessarily mean that 'development' has to be thrown overboard entirely, though one should be open to accept pluralistic meanings of 'development'; thus, its mainstream meaning may evolve over time. For now, the term 'development' is still needed as a bridge to future conceptualisations. In general, development is largely based on mainstream Western ideas that are targeted at growth and progress (Bateye 
et al., forthcoming; Kimmerle, 1998), including Western-based concepts such as 'capitalist, modernist, neoliberal, monocultural, extractivist and patriarchal' paradigms (Vásquez-Fernández and Ahenakew pii tai poo taa, 2020, p. 65).

The initial intention behind the concept of inclusive development was 'to counter the dominant neoliberal capitalist agenda' (Gupta et al., 2015, p. 541), based on the central idea that all stakeholders involved should benefit more equally. This was, however, only partly successful. Over time, inclusive development gained various meanings; for example, some put emphasis on inclusive growth while others put emphasis on ecological modernisation (Gupta and Pouw, 2017). A review by Gupta and Pouw (2017, p. 100) shows that despite the differences in meanings and approaches to inclusive development, it 'becomes apparent [...] that many of these approaches have been designed within the growth paradigm.' As such, inclusive development does not undermine mainstream Western ideas on growth and progress, but tries to repair its flaws by including actors who previously were excluded. Subsequently, Gupta and Pouw recommend that critical social science scholars should try to avoid thinking within this growth paradigm. Instead, Gupta and Pouw propose a shift is needed in which development is more discursively defined and emphasises the social, ecological, and relational (power) dimensions of development. In this chapter we aim to contribute to this shift in thinking by addressing the epistemological and ontological dimensions of inclusive development, which have gained little attention so far.

We explore to what extent 'inclusive development' can accommodate philosophies from the Global South and how the definition of inclusive development needs to be adjusted. We will do this by presenting perspectives from the Global South through two indigenous philosophies: Ubuntu and Buen Vivir. We present some characteristics and critiques on both philosophies as well as parallels and differences between the two-based on a literature study and Van Norren's PhD research (2017). We then explore how these two indigenous philosophies relate to the concept of 'inclusive development' and raise several issues to pay attention to when moving towards epistemic diversity.

\section{The epistemological dimension of inclusive development}

To start with, a central point of inclusive development is the need to involve all stakeholders and their knowledge - in particular, marginalised groups. As Gupta et al. (2015) write: 'inclusiveness includes the knowledge and aspirations of local people in the development process [...] and enhances their participation in decision-making' (Gupta et al., 2015, p. 546); meaning that indigenous knowledge should be included in the decision-making process. However, one can question the extent to which this also happens, in practice, in decisions about the concept of development itself. Inclusive development projects and policies may invite more diversity and marginalised people to the table even while, simultaneously, historically marginalised epistemologies continue being excluded (Boogaard, 2021). For example, a recent study of a livestock development project in a 
multi-stakeholder platform in Mozambique showed that the involved research organisation, the NGO, and the donor had set the definition of development prior to the start of the project, and this definition was not open to debate throughout the project (Boogaard, 2021).

The epistemological dimension of inclusive development thus refers to the involvement of indigenous people and their knowledge in development processes, especially with regard to the development concept itself. In the same line as the example above, we see that the majority of Sustainable Development Goals (SDGs) lean heavily on Western ideas about 'development' that are rooted in modernist economics and 'sustainable' growth-such as the target of 7\% (sustained, inclusive) growth in SDG8 - which largely excludes indigenous worldviews (Van Norren, 2017; Vásquez-Fernández and Ahenakew pii tai poo taa, 2020). As such, we see few attempts to include the knowledge of indigenous peoples in SDGs despite the formidable multi-stakeholder process that took place to draw up SDGs under the auspices of the United Nations (Van Norren, 2017). The exclusion and systematic and structural suppression of African, Latin American, Asian, and other indigenous philosophies and ways of knowing and doing constitutes epistemic injustice (Ramose, 2019; Sousa Santos, 2014). It is worrisome that development scholars have paid limited attention to African philosophies such as Ubuntu and Latin American philosophies such as Buen Vivir. For example, until today African philosophies are largely absent in debates on agricultural development in Africa (Boogaard, 2019).

In the current chapter, these two philosophies have been selected for the following reasons: (1) both have been historically excluded from mainstream development theories; (2) both have different epistemological roots compared to mainstream Western (economic) scientific knowledge; and (3) both offer a counter-hegemonic view on mainstream development views of economic progress and growth, meaning that they embrace concepts which go against the underpinnings of these paradigms. In addition to these three commonalities, there are also important differences between the two philosophies which we will address further on. We selected several characteristics as well as critiques that we deemed relevant in relation to the epistemological dimension of development, while being aware of the width and depth of both philosophies. ${ }^{3}$

\section{Ubuntu philosophy}

The term Ubuntu is found in many Sub-Saharan African languages; such as botho which has the same meaning in Sotho language, and hunhu in Shona language. Ubuntu is the fundamental ontological and epistemological category in the African thought of the Bantu people and as such can be described as the roots of African philosophies (Ramose, 1999, 2020). In Ramose's (2003, p. 271) words, 'The African tree of knowledge stems from ubuntu with which it is connected indivisibly.' In this section, we first describe Ubuntu philosophy by analysing three important African proverbs. ${ }^{4}$ 
To start with, ubu-ntu is a hyphenated word. Ubu- means the universe of being as enfolded-it is waiting to unfold. This is crucial, as it means that the philosophical point of departure is motion (not rest) and whole-ness (not fragmentation). The suffix -ntu refers to the process of unfolding through the knowing and speaking of humans. Umuntu can then be described as the living-a human being - in the visible world, while the living dead and yet-to-be-born are part of the invisible world, which together form the African community. It shows that relationality is central in African community, which is also expressed in the maxim 'umuntu ngumuntu nga bantu' in Zulu - translated as 'to be human is to affirm one's humanity by recognizing the humanity of others and, on that basis, establish human relations with them' (Ramose, 1999, p. 37). Throughout life and in relations with others, one needs to learn 'being human.' With regard to development, this means that development is not about accumulating wealth at the costs of other human beings or Nature. ${ }^{5}$ Instead, the maxim 'feta kgomo o thsware motho' in Sotho states that 'if and when one must make a choice between preserving human life and accumulating wealth then one ought to opt for the preservation of human life' (Ramose, 1999, p. 109). Thus, instead of accumulating and safeguarding individual wealth, mutual sharing and caring is more important. This means that personal accumulation of wealth is far less important than the economic and social wellbeing of the community. African life and philosophy thus focus on harmonious and inclusive human relations. Several philosophers place speculative capitalist practices-often for personal gain-as going against the interest of the collective (Ramose, 1999); this includes financial speculation but also property (housing) speculation ${ }^{6}$ or any speculation with other basic necessities, such as food. Equality and equity are moreover seen as cardinal values.

The importance of mutual caring and sharing is emphasised by a third Sotho maxim referring to the extended family: 'bana ba motho ba ngoathogana thogoana ya tsie,' meaning that the children of one family share even the head of a locust (Ramose, 2021): one has an ethical obligation to share even the smallest portion (the locust is small and its head even smaller), or as Wiredu (2003) stated, 'life is mutual aid.' Family here should not be narrowed to the Western concept of a household, but accept a broader meaning of the extended family, the clan and furthermore, fellow human beings in general. Mutual care not only relates to fellow human beings, but also to Mother Earth and non-humans (Ramose, 2004). Land is sacred, and the living dead should be thanked for leaving behind a healthy land, while the living should leave the land behind in a good condition and pay respect to it for the following generations (Kelbessa, 2015). Humans additionally have a moral responsibility towards Earth (Behrens, 2014). In terms of development this means that resources-and especially land-cannot be exploited endlessly, but should be treated with respect and harmony with the Earth and land should be maintained.

Summarising, these three maxims show that in Ubuntu philosophy relationality in the visible and invisible world - the spiritual, the ancestral, and the 
yet-to-be-born - as well as mutual sharing and caring are more important than the accumulation of individual wealth, or national growth of wealth, if this does not benefit the community including Nature as a whole.

\section{Buen Vivir (Sumak Kawsay) philosophy}

Buen Vivir (Good Living) originates from the Andean Quecha people from Peru, Bolivia, Ecuador, Chile, whose concept is called Sumak Kawsay, meaning the best way of living, living in plenitude, or the right way of living. Buen Vivir is both an indigenous concept and an environmental and political movement rooted in indigenous philosophies. Both Ecuador and Bolivia enshrined it in their Constitutions and national policies. It is a biocentric concept in which all life forms are considered equal and revolves around living in harmony with Nature, which is posited as leading to harmony in relations with others and with oneself. Mother Earth (Pachamama) is revered as the life-giver and considered sacred-and therefore written with a capital letter, just like Nature. It encapsulates a cyclical way of thinking, as opposed to mainstream Western linear thinking, and calls for balancing spiritual and material wealth (Acosta, 2015; Akchurin, 2015; Hidalgo-Capitán and Cubillo-Guevara, 2014; Government of Ecuador, 2013; Gudynas, 2011).

Because Pachamama is sacred, she has rights-just like all other living creatures in Nature, including humans. Therefore, the (right of) Mother Earth is the main principle on which all life is based and from this all other (human) systems are derived, such as law, governance, economics, and culture, which all need to operate in harmony with Nature/Earth. After the relationship with the Cosmos, Earth and Nature follows the relationship with the (human) community. The community of life encompasses all of the above (Villalba, 2013). Thus, there is no distinction between culture and Nature (Van Norren, 2017). For indigenous people Sumak Kawsay is not only tied to spirituality, but also to interculturality and plurinationality - namely the recognition of indigenous nations and territories within the state (Sousa Santos, 2014 given that their collective way of life cannot be practised without ties to the land, Nature, and territory.

As Sumak Kawsay is cyclical and not linear, it does not strive at accumulation of goods or economic growth; the main goal is balance and harmony through reciprocity-between humans and with Mother Earth and all living beings. As in Nature everything grows and decays, the idea of sustainability is, like growth, a false notion because sustainability suggests a system that is stable (with consistent linear growth) whereas in Nature everything moves in cycles. Hence Buen Vivir poses as an alternative to 'sustainable development' (Acosta, 2015; Thomson, 2011; Villalba, 2013). Like Ubuntu, Buen Vivir strives towards a selfsustaining and life-nurturing economy without growth in terms of accumulation of production and consumption. Instead, it sees economic speculation and centrality of capital as the greatest cause of the current exploitation of humans and Nature (Acosta, 2015). As such, it looks for solidarity and equal exchange 
whereby all living subjects are complementary to one another. This is called collective capability by Deneulin (2012); a capability which includes living in reciprocity with Nature. The capability theory was first developed by Amartya Sen in 'Development as Freedom' (Sen, 1999), which nevertheless looks only at individual human capabilities rather than collective capabilities, including all life. ${ }^{7}$

Building on this work, Van Norren (2017) proposes 'development as service' in addition to 'development as freedom.' Development could be redefined in terms of mutual service or reciprocity to one another and Earth/Nature. To this end, academic knowledge should be combined with knowledge of indigenous peoples (Oviedo-Freire, 2011) so that reciprocity in human relations as well as with Nature becomes central-and not the economy. Progress is then defined differently and this might lead to the abolishment of the word 'development' altogether. Such an approach would lead to a whole new economy which strives amongst others things at the redistribution of wealth and income; promoting post-extractivist economies and (community) markets, based on use value; decentralising production; realising energy and food sovereignty; inclusion of leisure and creativity; recognising domestic and reproductive work; and measuring the economy in terms of full employment (Acosta, 2015; Dávalos, 2008; Van Norren, 2020; Waldmüller, 2014).

\section{Several critiques on both philosophies}

Because this chapter does not allow for an in-depth discussion of detailed philosophical debates on the application and significance of Ubuntu and Buen Vivir, we will present a few more general critiques of both philosophies that are relevant in relation to knowledge and development. There is similarity between the critiques corresponding to each. One of the main criticisms of Ubuntu philosophy is that it romanticises the past and presents a one-sided view of who Africans are today. For example, the ethical imperative of mutual care and sharing may be read as presenting Africans as communitarian and Westerners as individualists. However, many publications have provided a more nuanced view in which one also finds individualism in African philosophies, as well as communalism in Western philosophies, though the emphasis is different in both cultures (Eze, 2008; Kimmerle, 2008; Oyeshile, 2006). Buen Vivir is subject to similar criticisms for romanticising the past. According to Bretón et al. (2014, p. 12) 'Medina [...] and Oviedo-Freire [...], from Bolivia and Ecuador respectively, have deployed a noticeable effort to build an archetypal, decontextualized and mystical image of a kind of carrier "Andean civilization" [...] uncontaminated for centuries by western culture,' so that ' $[\mathrm{t}]$ his type of approach to the subject has been ironically described as "pachamamista" from anti-essentialist visions.' Even though indigenous people are not immune to modernisation, they undeniably have a strong link to the land and Nature.

In addition, Buen Vivir and Ubuntu are criticised for being anti-market and anti-growth (Van Norren, 2017), while in many African and Latin American 
contexts there is a desire for improved standards of living. As such, an alternative view on growth and development should not mean that 'Africa should remain in a position of severe disadvantage' (Kimmerle, 1998, p. 27), but it means that wellbeing of the community is more important than personal accumulation of wealth. If applied on a world scale, this would imply a better distribution of worldwide economic gains (Oruka, 1995).

\section{Some parallels and differences between the two philosophies}

From the previous section's considerations, it becomes clear that there are several parallels between the two philosophies. In both philosophies, relationality is central in the sense that both philosophies have a sense of an expanded community derived from a cosmic unity that reaches into ancestral and future lives and includes Nature. From this follows a notion of equality between humans as well as other living beings. Relations are then at the heart of development, in which none is dominant over the other. In addition, both philosophies emphasise the reciprocity of life, and the need to recognise this and respect it as a fundamental principle. In Ubuntu we see that life is mutual aid-including reciprocity to the ancestors - and in Buen Vivir it is living in harmony with, and respect for, Mother Earth (Van Norren, 2017). Hence, both philosophies are not concerned with the idea of progress or development in purely material means but instead stress the importance of harmony and (spiritual) relations.

If we zoom in on both philosophies there are also differences, for example, in the importance of human and non-human relations. ${ }^{8}$ In Ubuntu philosophy inclusion of the human community comprises the living, the living dead and the yet-to-be-born, and the principle of mutual care also extends to Mother Earth and non-humans. It is, however, argued that African philosophies are essentially human-centred, as they mainly focus on relations between humans (e.g. Gyekye, 1997). In general, Ubuntu derives its relationship to Earth from the human interrelationships and dependence on land, as well as from its relationship with future generations as part of the 'bantu' community and the ancestors who are identified within the Earth (Van Norren, 2017). One could say that there are various interpretations of Ubuntu among Africans, which represent a position between anthropocentrism and biocentrism in which rural dwellers tend to be more biocentric. In Buen Vivir we saw that inclusion entails the whole community of life-with Nature and all living beings on an equal footing - that need to live in harmony with one another: humans are a tiny part of the spectrum. As such, Buen Vivir can be considered as biocentric (Acosta, 2015; Van Norren, 2017). Considering knowledge, in Ubuntu knowing is about 'being in relation' and 'feeling engaged with the other,' i.e., humanness. In Buen Vivir, knowing is being in harmony with the universe, Earth and Nature, and connecting to the Earth (Van Norren, 2017). 


\section{Towards epistemic diversity}

Ubuntu and Buen Vivir are therefore inherently inclusive cosmologies, in the sense that they emphasise interrelationship and embrace diversity as basic tenets: in the 'rainbow nation' and 'holoculturality' (Ubuntu); and in plurinationality and interculturality (Buen Vivir). As such, the term 'inclusive development' can be seen as a tautology from an Ubuntu and Buen Vivir perspective. In fact, 'inclusive development' is a Western-developed concept that was deemed necessary, as a model aiming for economic progress and meritocracy is inherently exclusive. Inclusive development definitions that are trapped 'within the neo-liberal fast growth paradigm' (Gupta and Pouw, 2017, p. 97), and that take 'big-D development logic' such as inclusive growth as a starting point, have a fundamentally different view compared to the described indigenous philosophies. In Ubuntu and Buen Vivir philosophies, the economy is not central in development. For Ubuntu, it is developing human relations and moral responsibility; for Buen Vivir it is developing harmony with Nature and Earth. Thus, Ubuntu and Buen Vivir may lead to an altogether different 'development' or, rather, wellbeing paradigm in which the 'harmony of all life' may become more central; based on reciprocity and relationality between human and non-humans, including Mother Earth, and the present, past, and future generations (Van Norren, 2017).

As such, Ubuntu and Buen Vivir philosophies can be a source of inspiration for degrowth scholars because 'ubuntu offers the philosophical basis for an alternative imaginary to growth and development' (Ramose, 2015, p. 213). In addition, there are some parallels between Buen Vivir and environmental justice and deep ecology (Van Norren, 2017). In that sense, Ubuntu and Buen Vivir philosophies may be not entirely incommensurable with alternatives within the inclusive development discourse, though their scope is much wider.

However, there is a high risk of knowledge appropriation if one seeks to include indigenous philosophies in current narratives. This would make other knowledges part of dominant existing-and often Eurocentric-concepts. This was partly the case in Ecuador, where the extractive economy remained and became more dominant during Buen Vivir government policies instead of emulating the intrinsic value of Nature. Walsh (2010, p. 17) states that Buen Vivir may not 'disentangle Ecuador from its colonial past, but possibly entangles it with the development paradigm in a more complex way. It is in danger of becoming part of "the European push to humanize capitalism." Likewise, the targets and indicators in the SDGs, are based on the idea that 'knowing is measuring,' whereas indigenous philosophies are not exclusively based on empiricist measuring but on other ways of knowing.

The concept of 'inclusive development' can become less Eurocentric by making room for, and subsequently being transformed by, indigenous philosophies: not as tokens or knowledge appropriation but by fundamentally questioning the concept of development (Vásquez-Fernández and Ahenakew pii tai poo taa, 2020). How can we move towards epistemic diversity? To start with, it would 
be a misunderstanding to assume that epistemic diversity is a harmonious process of bringing different knowledges seamlessly together. Instead, it is a process of negotiation and struggle between epistemologies, in which a reality of diversities is accepted; there may be overlaps as well as gaps and tensions between values, epistemologies, and ontologies (Ludwig and El-Hani, 2019). For example, both Ubuntu and Buen Vivir emphasise the importance of the relationship with the land (Vásquez-Fernández and Ahenakew pii tai poo taa, 2020), but there are huge tensions between such relationality to the land of indigenous peoples and current legal and economic systems revolving around private property and ownership of land; this includes the individualist human rights tradition that holds private property sacred. As such, negotiation between diverse types of knowledge and ways of knowing is needed to create space and recognition for epistemic diversity in the first place (Roothaan, 2019).

From this departure point, we propose to engage in mutually transformative dialogues between development scholars and philosophers in the Global South and North (following Kimmerle, 1998, 2012). Until today, international development debates tend to be dominated by narratives originally formulated by Western-trained scholars who-consciously or unconsciously-exclude indigenous philosophies. However, over the past decades, African and Latin American philosophers and other intellectuals have been-and continue to be-deeply engaged in questioning, thinking, discussing, reflecting, and acting on what development means from African or Latin American perspectives (Acosta, 2015; Agbakoba, 2019; Diagne and Kimmerle, 1998; Hountondji, 2004). To include the epistemological dimensions of development means to decolonise people's mindsets. Historically dehumanising experiences of slavery and colonialism still influence international relations between the Global South and Global North in the sense that these relations continue to be characterised by highly unequal power relations. While it is widely acknowledged that economic relations between the Global South and North are unequal, inequality in epistemological relations has gained less attention so far. In response to ongoing forms of dehumanisation, Ramose (2020) therefore argues that we need 'mothofatso'; to re-humanise human relations, as echoed by authors like Acosta (2015).

A dialogical approach towards the epistemological dimensions of inclusive development may ask a more modest attitude from Western-trained scholars, and requires a willingness to listen and learn from indigenous philosophies (Kimmerle, 2012), in order to avoid that these philosophies are declared irrelevant and forgotten altogether or framed unjustly and too quickly in a dominant Western concept of inclusive development.

\section{Conclusion}

Based on the above, we argue that as long as African, Latin American, and other indigenous philosophies remain excluded from the concept of inclusive development, we will reproduce Eurocentric and neo-colonial ideas of development 
based on Western frameworks and theories that are easily imposed on 'nonWestern' contexts. ' Learning from Ubuntu and Buen Vivir philosophies, the present study provides at least four points on the epistemological and ontological dimensions of 'inclusive development':

(1) A need to broaden the concept and definition of 'inclusive development,' which includes fundamental and critical questions about the epistemologies on which the current concept of 'inclusive development' is founded. This requires a recognition of the existence, the value, and a better understanding of philosophies from the Global South.

(2) A need to recognise epistemic diversity and to question the concept of 'development,' which from a perspective of indigenous philosophies of the Global South would be more adequately described through (human) wellbeing, relationality, and harmony. This includes the requirement to rehumanise human relations, so that reciprocity in human relations as well as with Nature is central.

(3) A need to avoid knowledge appropriation, but instead engage in mutually transformative dialogues. This is perhaps the greatest danger: that Ubuntu and Buen Vivir will be paid lip service in future development reports and schemes, such as the SDGs, without taking full cognisance of them.

(4) A need to put harmony with Nature and respect for the Earth central to human thinking and to recognise the rights of the Earth and Nature as intrinsic and equal to that of human rights, as is done in Buen Vivir and the constitution of Ecuador.

\section{Notes}

1 Both authors contributed equally to this article.

2 'Development' is a contested and Eurocentric concept; therefore, we purposely put it between inverted commas. Likewise, we also purposely put the terms 'developing' and 'developed' between inverted commas.

3 Such a selection process is not neutral, especially given the Western educational and cultural background of both authors.

4 Over the past two decades, Ubuntu has been widely debated among African philosophers, particularly in South Africa, e.g. in the South African Journal of Philosophy.

5 Written with a capital to denote its sacredness for indigenous communities.

6 South African jurisprudence also offers very strong protection against eviction from housing, so that the interest of the private owner is subservient to the interests of the renters (Cornell and Muvangua 2012; Van Norren, 2017).

7 Sen (1999) articulates individual capabilities to reach valuable functionings and doings and to realise human rights and freedoms. Sen redefined development/progress thinking into actualising one's individual valuable states of being and doing, while 'development as service' adds the collective dimension.

8 We will mention some salient differences here. For a more extensive list see Table 9.3 'Comparison of SDG, Ubuntu, Happiness, Buen Vivir approach" in Van Norren (2017, p.320).

9 The term 'non-Western' is problematic in itself: it is a Eurocentric view towards indigenous philosophies that continues to refer to 'the West' as reference point. 


\section{References}

Acosta, A. (2015). Buen Vivir. Vom Recht auf ein gutes Leben. Munich: Oekom Verlag.

Agbakoba, J. C. A. (2019). Development and modernity in Africa: An intercultural philosophical perspective. Cologne: Rüdiger Köppe Verlag.

Akchurin, M. (2015). Constructing the Rights of Nature: Constitutional reform, mobilization, and environmental protection in Ecuador. Law and Social Inquiry, 40(4), 937-968.

Bateye, B., Masaeli, M., Müller, L., and Roothaan, A. (forthcoming) (eds.). Beauty in African thought: A critique of the Western idea of development. Lanham: Lexington.

Behrens, K. (2014). An African relational environmentalism and moral considerability. Environmental Ethics, 36(1), 63-82.

Boogaard, B. K. (2019). The relevance of connecting sustainable agricultural development with African philosophy. South African Journal of Philosophy, 38(3), 273-286.

Boogaard, B. K. (2021). Epistemic injustice in agricultural development: Critical reflections on a livestock development project in rural Mozambique. Knowledge Management for Development Journal. 16(1), 28-54.

Breton, V., Cortez, D. and García, F. (2014). En busca del Sumak Kawsay: In search of Sumak Kawsay, introduction to the dossier. Íconos. Revista de Ciencias Sociales, 48, 9-24.

Cornell, D. and Muvangua, N. (eds.). (2012). Ubuntu and the law: African ideals and postapartheid jurisprudence. New York: Fordham University Press.

Dávalos, P. (2008). Reflexiones sobre el Sumac Kawsay (Buen Vivir) y las teorías del desarrollo. ALAI (Agencia Latino Americana Informaciones). http://www.alainet.org/es/active $/ 25617$

Deneulin, S. (2012). Justice and deliberation about the Good Life: The contribution of Latin American Buen Vivir social movements to the idea of justice. Bath papers in international development and wellbeing, 17, Centre for Development Studies, University of Bath.

Diagne, S. B. and Kimmerle, H. (eds.). (1998). Time and development in the thought of Subsaharan Africa. Studies in Intercultural Philosophy, 8, Rodopi B.V.

Eze, M. O. (2008). What is African communitarianism? Against consensus as a regulative ideal. South African Journal of Philosophy, 27(4), 386-399.

Government of Ecuador (2013). National development plan, National Plan for Good Living 2013-2017, a better world for everyone. Summarized Version. Republic of Ecuador.

Gudynas, E. (2011). Good life: Germinating alternatives to development. Latin America in Movement, (ALAI), July 14. http://www.alainet.org/es/node/151207

Gupta, J. and Pouw, N. (2017). Towards a trans-disciplinary conceptualization of inclusive development. Current Opinion in Environmental Sustainability, 24, 96-103.

Gupta, J., Pouw, N. R. M. and Ros-tonen, M. A. F. (2015). Towards an elaborated theory of inclusive development. The European Journal of Development Research, 27(4), 541-559.

Gyekye, K. (1997). Tradition and modernity. Philosophical reflections on the African experience. Oxford: Oxford University Press.

Hidalgo-Capitán, A. L. and Cubillo-Guevara, A. P. (2014). Six open debates on Sumak Kawsay. Íconos Revista de Ciencias Sociales, 48, 25-40.

Hountondji, P. (2004). Knowledge as a development issue. In: Wiredu, K. (2007) A companion to African philosophy. Oxford: Blackwell Publishing, 529-537.

Kelbessa, W. (2015). African environmental ethics, indigenous knowledge, and environmental challenges. Environmental Ethics, 37(4), 387-410. 
Kimmerle, H. (2012). Dialogues as form of intercultural philosophy. Irian Society of Intercultural Philosophy. http://isiph.ir/en/?p=27

Kimmerle, H. (2008). The concept of person in African thought: A dialogue between African and Western philosophies In: Wautischer, H. (ed.). Ontology of Consciousness. Cambridge: MIT Press, 507-524.

Kimmerle, H. (1998). The concept of time as key-notion for new ideas about development. In: Diagne, B. and Kimmerle, H. (eds.). Time and development in the thought of Subsaharan Africa. Studies in intercultural philosophy 8. GA. Amsterdam: Rodopi B.V.

Ludwig, D. and El-Hani, C. (2019). Philosophy of ethnobiology: Understanding knowledge integration and its limitations. Journal of Ethnobiology, 40(1), 3-20.

Oruka, H. O. (1995). Ecophilosophy and the parental Earth ethics (on the complex web of being). In: Oruka, H. O., Graness, A. and Kresse, K. (eds.). Sagacious Reasoning: Henry Odera Oruka in Memoriam, Bern: Peter Lang, 119-131.

Oviedo-Freire, A. (2011). Qué es el Sumakawsay. Más álla del capitalismo y el socialismo. Camina alter-nativo al desarollo. Una propuesta para los 'indignados' y démas desencantados de todo el mundo. La Paz: Sumak Editores.

Oyeshile, O. (2006). The individual-community relationship as an issue in social and political philosophy. In: O. Oladipo (ed.). Core issues in African philosophy. Hope Publications, 102-116.

Ramose, M. B. (2003). The philosophy of ubuntu and ubuntu as a philosophy. In: Coetzee, P. H. and Roux, A. P. J. (eds.). The African philosophy reader. Second edition. London: Routledge, 270-280.

Ramose, M. B. (2004). The Earth 'mother' metaphor: An African perspective. In: Elders, F. (ed.). Visions of nature. Studies on the theory of Gaia and culture in ancient and modern times. Brussels: VU University Press, 203-206.

Ramose, M. B. (2015). Ubuntu. In: D'Alisa, G., Demaria, F. and Kallis, G. (eds.). Degrowth, A vocabulary for a new era. London: Routledge, 212-213.

Ramose, M. B. (2020). Critique of Ramon Grosfoguel's 'The epistemic decolonial turn'. Alternation, 27(1), 271-307.

Ramose, M. B. (1999). African philosophy through Ubuntu. Harare: Mond Books Publishers.

Ramose, M. B. (2021). Ethical responsibility for the other arrested by epistemic blindness, deafness and muteness: An ubuntu perspective. In: Standish, K., Devere, H., Suazo, A. and Rafferty, R. (eds) The Palgrave Handbook of Positive Peace. Singapore: Palgrave Macmillan, 1-25.

Ramose, M. B. (2019). A philosophy without memory cannot abolish slavery: On epistemic justice in South Africa. In: Hull, G. (ed.). Debating African philosophy. Perspectives on identity, decolonial ethics and comparative philosophy. Routledge, 60-72.

Roothaan, A. (2019). Indigenous, modern and postcolonial relations to Nature: Negotiating the environment. London: Routledge.

Sen, A. (1999). Development as Freedom. Oxford: Oxford University Press.

Sousa Santos, B. de (2014). Epistemologies of the South. Justice against epistemicide. London: Routledge.

Thomson, B. (2011). Pachakuti: Indigenous perspectives, Buen Vivir, Sumaq Kawsay and degrowth. Development, 54(4), 448-454.

Van Norren, D. E. (2017). Development as service. A Happiness, Ubuntu and Buen Vivir interdisciplinary view of the Sustainable Development Goals. PhD dissertation, Tilburg University. 
Van Norren, D. E. (2020). The sustainable development goals viewed through gross national happiness, Ubuntu, and Buen Vivir. International Environmental Agreements: Politics, Law and Economics. 20(3), 431-458.

Vásquez-Fernández, A. M. and Ahenakew pii tai poo taa, C. (2020). Resurgence of relationality: Reflections on decolonizing and indigenizing 'sustainable development'. Current Opinion in Environmental Sustainability, 43, 65-70.

Villalba, U. (2013). Buen Vivir vs development: A paradigm shift in the Andes? Third World Quarterly, 34(8), 1427-1442.

Waldmüller, J. M. (2014). Buen Vivir, Sumak Kawsay, Good Living: An Introduction and Overview. Alternautas, (Re)Searching Development: The Abya Yala Chapter, extended version. http://www.alternautas.net/blog/2014/5/14/buen-vivir-sumak-k awsay-good-living-an-introduction-and-overview.

Walsh, C. (2010). Development as Buen Vivir. Institutional arrangements and (de) colonial entanglements. Development, 53(1), 15-21.

Wiredu, K. (2003). The moral foundations of an African Culture. In: Coetzee, P. H. and Roux, A. P. J. (eds.). The African philosophy reader. Second edition. London: Routledge, 287-296.

Ziai, A. and Escobar, A. (2007). Exploring post-development: Theory and practice, problems and perspectives. London: Routledge. 